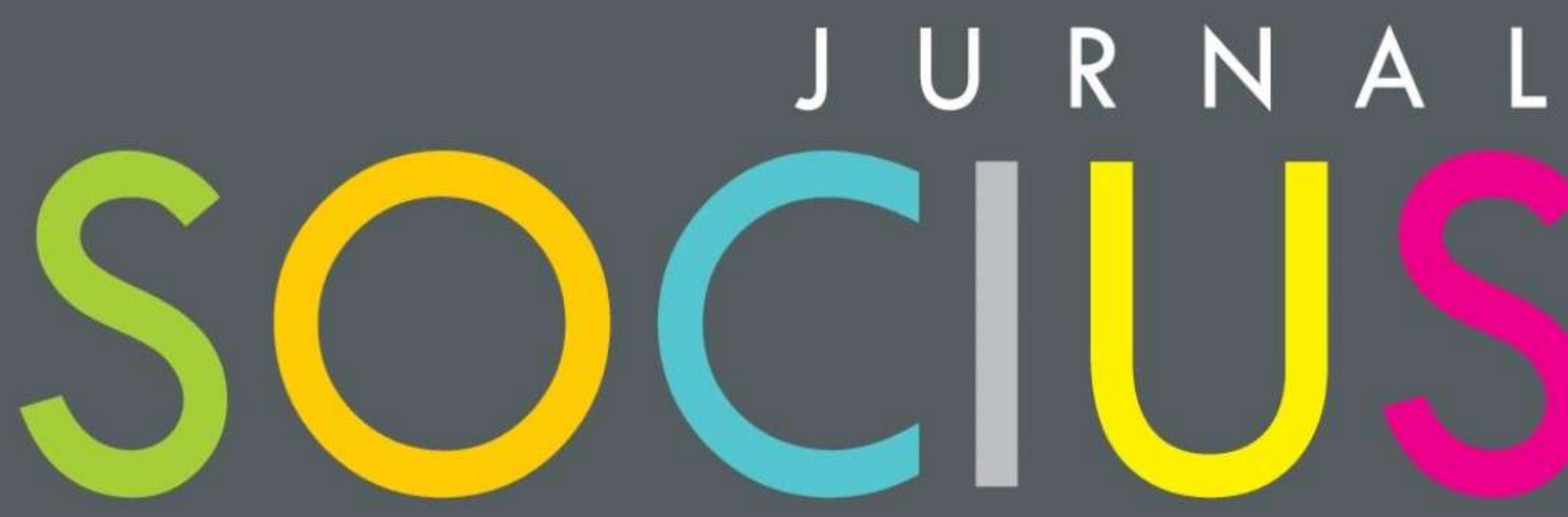

Journal of Sociology Research and Education

DITERBITKAN OLEH :

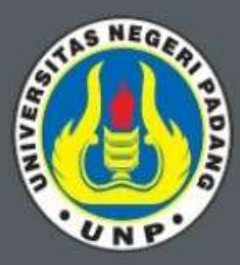

LABOR JURUSAN SOSIOLOGI FAKULTAS ILMU SOSIAL UNIVERSITAS NEGERI PADANG

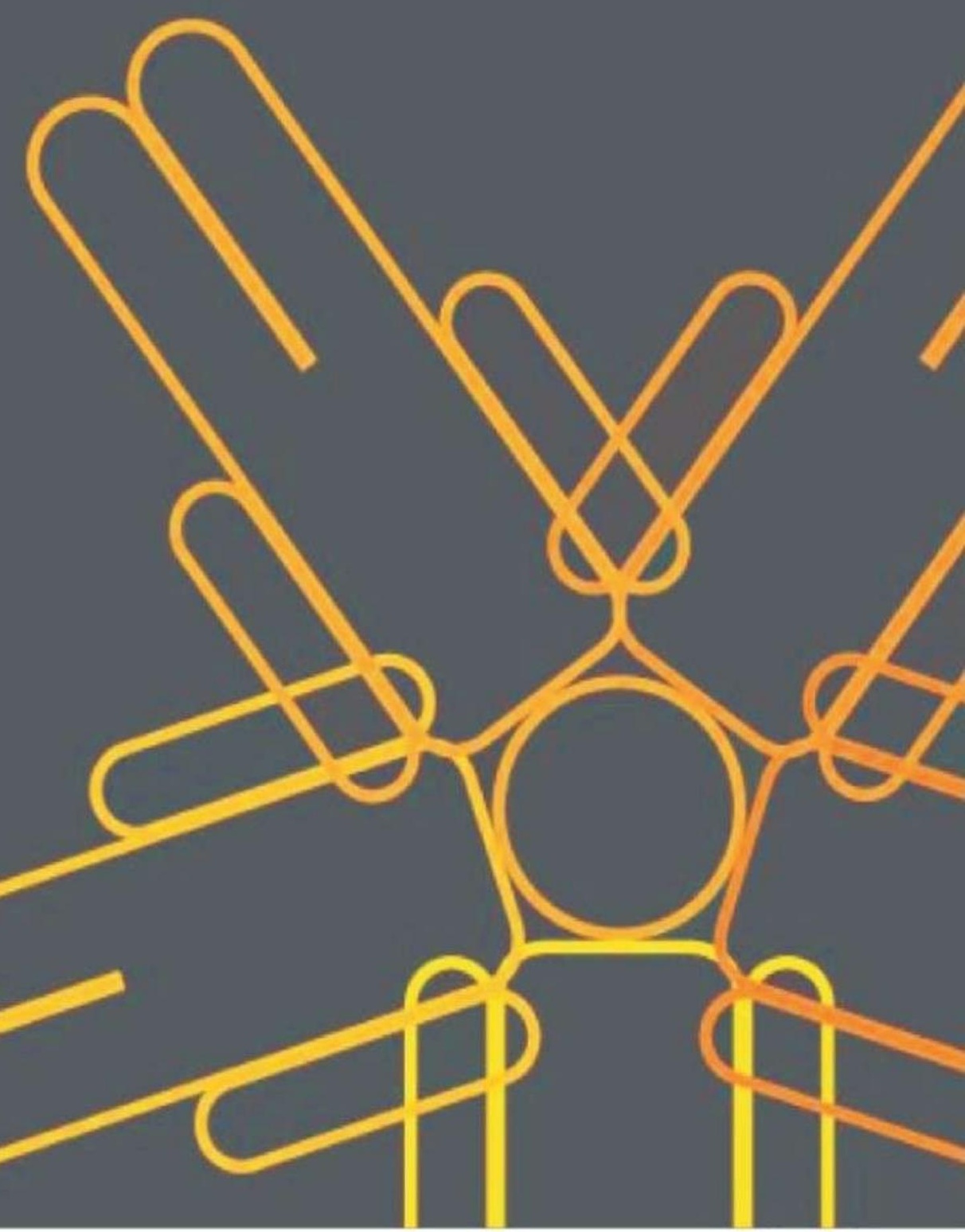




\section{SOCIUS}

Vol. 6, No.1, Th. 2019

ISSN : 2356-4180 (cetak)

2442-8663 (online)

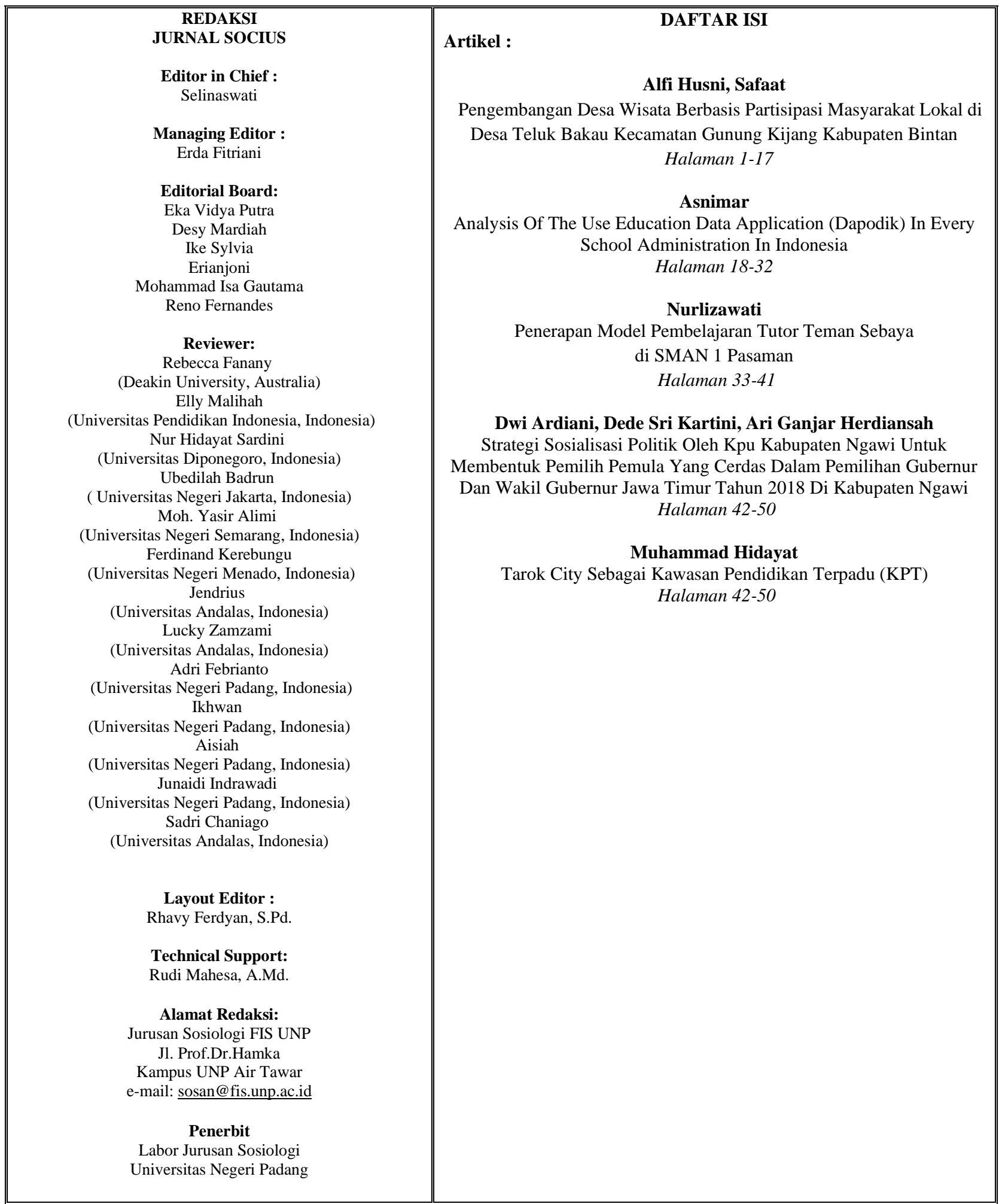




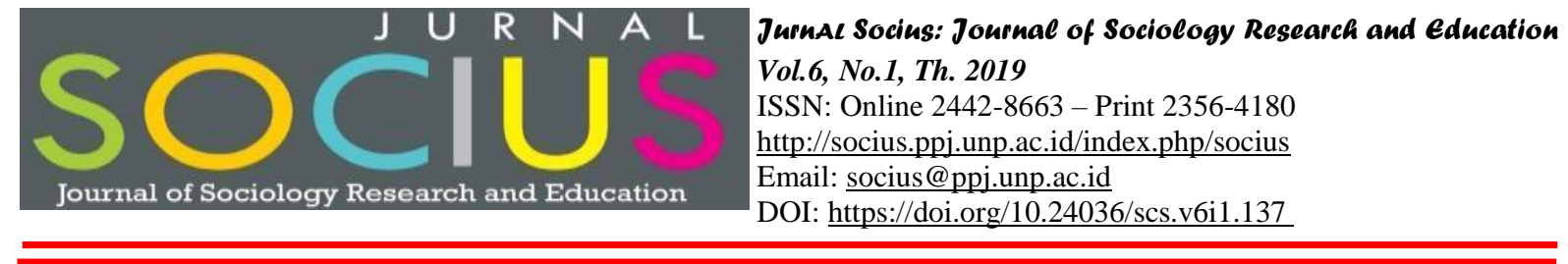

\title{
TAROK CITY SEBAGAI KAWASAN PENDIDIKAN TERPADU (KPT) (STUDI ANALISIS KESIAPAN MASYARAKAT NAGARI DALAM PEMBANGUNAN KPT)
}

\author{
Muhammad Hidayat \\ Universitas Negeri Padang \\ Email: ikanperak08@gmail.com
}

\begin{abstract}
Abstrak
Perencanaan kawasan pendidikan terpadu ini oleh Bupati Pariaman, dengan lembaga yang terkait pembangunan kawasan pendidikan terpadu adalah salah satu usaha pembangunan strategis bertujuan untuk kesejahteraan ekonomi masyarakat dan pembangunan di bidang pendidikan. Rencana ini masih menyimpan banyak persoalan, diantaranya adanya ketidaksetujuan masyarakat terhadap pembangunan tersebut, tuduhan terhadap perebutan lahan tanah ulayat dan penggantian rugi lahan mayarakat yang tidak sesuai dan lainnya. Penelitian ini bertujuan untuk mengetahui dan menjelaskan kesiapan dan keterbukaan masyarakat untuk pembangunan Kawasan Pendidikan Terpadu. Penelitian dilakukan dengan pendekatan kualitatif, dengan metode pengumpulan data observasi, wawancara dan studi dokumen. Hasil penelitian menunjukkan bahwa masyarakat tidak siap dengan akan dibangunnya Kawasan Pendidikan Terpadu (KPT) di Tarok City. Hal ini terlihat dari rendahnya antusiasme dan tingkat partisipasi lembaga masyarakat yang dibuktikan masih belum tuntasnya sengketa tanah ulayat dan kesepakatan ganti rugi yang tak kunjung ada penyelesaian.
\end{abstract}

Kata Kunci: Kesiapan masyarakat, Perencanaan Pembangunan, Partisipasi masyarakat, Lembaga Masyarakat

\begin{abstract}
The planning of integrated education area Kawasan Pendidikan Terpadu (KPT) Tarok City, Pariaman is deemed as one the strategic development efforts which are aimed to create the economic well being of the community and development of education. The area is strategic and prospective enough since the location at the edge of The Padang-Bukittinggi nation road. However, this development program still has a lot of problems; including the resistence of public pertaining to continuity of development, allegation against the seizure of communal land and compensation for the loss of community land. This study aims to determine whether community institution are ready to manage the development activities. The study was conducted by collecting qualitative, with data collection namely observation, interviews and document studies. The results shows that the community is not too prepared for the establishment of integrated education area (KPT) at Tarok City. This can be seen in the less enthusiasm and level of participation of the Community institutions, as evidenced by the incomplete customary land dispute and the non existent compensation agreement.
\end{abstract}

Keyword: Community prepradness, Development planning, Community institutions, Community participation

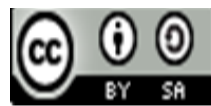

Received: February 12, 2019

Revised: June 29, 2019

Available Online: June 30, 2019

Jurnal Socius: Journal of Sociology Researn and Education Vol. 6, No.1, Th. 2019

ISSN: Online 2442-8663 - Print 2356-4180 


\section{Pendahuluan}

Pembangunan merupakan usaha besar-besaran untuk mempercepat proses transisi sosialbudaya dengan rencana-rencana yang disusun dengan sengaja secara khusus (Koentjaraningrat, 1982). Pembangunan yang dilaksanakan pemerintah Indonesia selama ini tidak hanya bersifat fisik semata, tetapi juga bersifat non fisik. Pembangunan non fisik disebut sebagai pembangunan masyarakat yang berada di sekitar area pembangunan. Masyarakat di sekitar area pembangunan umumnya memiliki beragam kelompok-kelompok yang unik dengan kebiasaan dan nilai-nilai berbeda dengan kelompok lain. Meskipun dalam perencanaan pembangunan yang akan dilaksanakan dianggap sempurna secara fisik, namun dalam pelaksanaannya pembangunan seringkali mengalami sejumlah permasalahan di bidang non fisik seperti bidang sosial-budaya. Agar rencana pembangunan tersebut dapat disusun dengan cermat dan teliti, perlu diadakan penulisan-penulisan terhadap sejumlah masalah sosial-budaya tertentu dengan metodologi pendekatan yang khusus.

Meskipun pemerintah memiliki grand design pembangunan fisik dengan corak budaya daerah dengan melibatkan berbagai institusi formal dan non formal, tetap saja tidak mudah menjelaskan hubungan pembangunan fisik dan pembangunan non fisik dalam masyarakat. Pembangunan fisik tersebut selain memiliki standar pembangunan yang dibuktikan dengan Izin Lingkungan berstandar pembangunan nasional. Mempertanyakan pembangunan fisik untuk pembangunan non fisik merupakan diskusi yang rumit karena terkait dengan kebudayaan dan eksistensi dari sejumlah tindakan manusia. Pembangunan yang dilaksanakan pemerintah bertujuan membangun masyarakat dan peradaban masyarakat. Keterkaitan pembangunan dengan masyarakat terdapat pada proses menata dan mengembangkan pranata- pranata atau nilai-nilai dalam masyarakat. Di mana nilai menjadi inti dan basis bagi tindakan manusia. Himpunan nilai-nilai yang menata serangkaian tindakan berpola mantap guna memenuhi suatu keperluan khusus dalam kehidupan masyarakat disebut Koentjaraningrat (1996) sebagai Social Institution, Soerjono Soekanto (1998) menyebutnya sebagai Institusi atau Asosiasi, W.G. Sumner (1940) menyebutnya sebagai folkways.

Pembangunan yang dilaksanakan tidak hanya sebatas pertumbuhan ekonomi (economic growth) terhadap masyarakat disekitar, tetapi menjadi pembangunan yang berpradigma berkelanjutan (sustainable devalopment) terhadap nilai, dan perilaku pada kelompok atau lembaga masyarakat di sekitar kawasan pembangunan. Lembaga kemasyarakatan menempati kedudukan strategis bagi usaha-usaha perubahan dan pembangunan, karena lembaga mempunyai keleluasan dalam bertindak dan memiliki kekuatan dalam mengadakan perubahan dan pembangunan masyarakat. Adapun jenis lembaga tersebut diantaranya lembaga adat, lembaga sosial, lembaga pendidikan, lembaga negara dan lainnya. Beberapa defenisi konsep dikemukakan oleh para ahli seperti yang dikemukan oleh Siagian, Ginanjar Kartasasmita dan Alexander dan Portes (Badruddin,2009).

Perubahan kawasan yang dulunya adalah kawasan pertanian berganti dengan menjadi kawasan pedidikan terpadu akan mengalami permasalahan nilai dan perilaku baru pada sekitar masyarakat yang berada di area pembangunan. Menurut Roger (1983) setiap orang individu memiliki kemungkinan mengadopsi pembangunan. Adopsi pembangunan berlangsung jika menguntungkan bagi pihak masyarakat maka pembangunan akan digunakan oleh mereka. Pembangunan mampu mempengaruhi partisipasikelembagaan masyarakat terhadap pembangunan yang akan dilaksanakan. Melalui partisipasimasyarakat dapat mengukur dan memetakan kondisi kesiapan masyarakat terhadap pembangunan yang sedang dilaksanakan oleh pemerintah.Proses pelaksanaanpembangunan merupakan proses yang bersifat berkelanjutan, yang bertujuan mnmpermudah dan membantu persoalan dalam kehidupan masyarakat. Pembangunan dapat berupa pembangunan area industri, pendidikan, perdagangan, penemuan teknologi dan alat baru dan lainnya. 
Secara khusus penulisan ini menggali kesiapanmasyarakat terhadap pembangunan di kawasan Pembangunan Kawasan Terpadu di Tarok City. Kawasan ini berada pada Nagari Kapalo Ilalang, Kecamatan 2 x 11 Kayu tanam Kabupaten Padang Pariaman.Pembangunan Tarok City ini pernah ditolak masyarakat melalui demonstrasi yang dilakukan pada tanggal 8 Mei 2017 di depan DPRD Sumatera Barat ( harian haluan, com) dan tanggal 27 September 2017 di depan DPRD Pariaman. Bagi masyarakat yang memprotes kebijakan tersebut menganggap Bupati ini telah merebut tanah ulayat mereka, tidak memberikan ganti rugi yang sama. Ditambah dengan adanya beberapa tokoh politik lainnya yang ikut memprotes kebijakan Bupati Pariman Ali Mukni tentang pembangunan Tarok City. Kontraversi ini menunjukkan adanya persoalan nilai dan perilaku masyarakat terhadap pembangunan yang sedang dilaksanakan.

Tabel 1. Kronologis yang telah dilakukan oleh pihak pemerintah

\begin{tabular}{|c|c|c|c|}
\hline No & Tanggal & Peristiwa & Pelaku \\
\hline 1 & 15 Desember 2016 & $\begin{array}{lccc}\text { Koordinasi dengan } & \text { Ketua } & \text { DPRD, } \\
\text { Forkompindo dan OPD } & & \\
\end{array}$ & Bupati \\
\hline 2 & 19 Februari 2017 & Kelanjutan Rekonsiliasi & \\
\hline 3 & 5 Mei 2017 & Asrizal dan Khairul dukung pembangunan & $\begin{array}{l}\text { Tokoh } \\
\text { Masyarakat }\end{array}$ \\
\hline 4 & 11Mei 2017 & $\begin{array}{l}\text { Dukungan dari tokoh agama: Duski Samad } \\
\text { terhadap Pembangunan }\end{array}$ & $\begin{array}{l}\text { Tokoh } \\
\text { Masyarakat }\end{array}$ \\
\hline 5 & 16 Juni 2017 & $\begin{array}{l}\text { Bupati Menyerahkan Tanah kepada } \\
\text { Lembaga Administrasi Negara }\end{array}$ & Bupati \\
\hline 6 & 3 Juli 2017 & $\begin{array}{l}\text { Penandatanganan MoU dengan Lembaga } \\
\text { Administrasi negara }\end{array}$ & $\begin{array}{l}\text { Bupati, } \\
\text { Gubernur } \\
\text { LAN }\end{array}$ \\
\hline 7 & 9 Juli 2017 & $\begin{array}{lr}\text { Warga } & \text { Muhammadiyah } \\
\text { Mendukung Pembangunan } & \text { Asiah } \\
\end{array}$ & Masyarakat \\
\hline 8 & 27 September 2017 & Demo Masyarakat di Kantor DPRD & $\begin{array}{l}\text { FPTUN Kapalo } \\
\text { Hilalang }\end{array}$ \\
\hline 9 & 30 September 2017 & Dukungan wali nagari untuk pembanguan & Wali Nagari \\
\hline 10 & 17 November 2017 & $\begin{array}{l}\text { Status Tanah dianggap Clear dan clean } \\
\text { Tanah Negara }\end{array}$ & BPN dan Kejari \\
\hline 11 & 27 November 2017 & $\begin{array}{l}\text { Puluhan masyarakat menyebut tanah } \\
\text { mereka dirampas oleh Bupati dan meminta } \\
\text { meninjau ulang kepada DPRD }\end{array}$ & Masyarakat \\
\hline 12 & $\begin{array}{l}4 \quad \& \quad 16 \text { Desember } \\
2017\end{array}$ & Rektor UNP mengunjungi Kawasan & $\begin{array}{l}\text { Rektor UNP dan } \\
\text { Tim }\end{array}$ \\
\hline 13 & 28 Desember 2017 & $\begin{array}{l}\text { Dukungan Edi, tokoh masyarakat untuk } \\
\text { pembangunan }\end{array}$ & $\begin{array}{l}\text { Tokoh } \\
\text { Masyarakat }\end{array}$ \\
\hline 14 & 4 Januari 2018 & $\begin{array}{l}\text { Dukungan harian Singgalang terhadap } \\
\text { pembangunan }\end{array}$ & Media \\
\hline
\end{tabular}

Sumber: Diolah dari beberapa Media Koran, 2018

Dari uraian di atas terlihat adanya persoalan kontroversi antara lemabaga formal dan non formal terhadap pembangunan Tarok City sebagai Kawasan Pendidikan Terpadu, baik dari kalangan tokoh politik maupun dari kalangan masyarakat yang menyebut diri mereka sebagai Forum Pembela Tanah Ulayat (FPTU) Nagari Kapalo Hilalang. Pentingnya pemahaman terhadap lembaga masyarakat tersebut untuk memahami persoalan kelembagaan Masyarakat Tarok City Kabupaten Padang Pariaman. Persoalan tersebut meliputi nilai 
masyarakat, sikap masyarakat dan kesiapanmasyarakat terhadap penerimaan rencana pembangunan tersebut.

Munculnya demonstrasi masyarakat yang mengatasnamakan kelompok mereka sebagai Forum Pembela Tanah Ulayat (FPTU) menunjukkan reaksi ketidak setujuan masyarakat terhadap rencana pembangunan yang akan dilaksanakan oleh pemerintah. Artinya masih ada persoalan yang belum terselesaikan antara pemerintah dan masyarakat sekitar, terutama tentang masalah tanah. Tanah bagi masyarakat merupakan sumber kehidupan dan modal kehidupan budaya mereka. Tanpa tanah mereka bukanlah apa-apa. Tanah merupakan sumber ekonomi untuk memenuhi kebutuhan mereka. Maka tanah merupakan hal terpenting bagi mereka. Dalam istilah Belanda hak tanah mereka disebut dengan Adat Recht atau disebut juga sebagai Tanah Ulayat. Tanah Ulayat disebut juga sebagai tanah kepemilikan bersama atau tanah komunal. Tanah Ulayat di Minangkabau dapat dibedakan menjadi; 1) Tanah Ulayat Nagari, 2) Tanah Ulayat suku dalam nagari, 3) Tanah Ulayat pusaka kaum dalam nagari, 4) Tanah Ulayat tempelan (Erwin, 2011).

Sekalipun adanya dukungan pemerintah terhadap pembangunan Tarok City dan demontrasi oleh kalangan masyarakat, maka penulisan terhadap kesiapanmasyarakat menjadi penting untuk dikaji lebih jauh. Apa penyebab munculnya demonstrasi di kalangan masyarakat? Kenapa pemerintah tidak menanggapi demonstrasi di kalangan masyarakat pembela tanah ulayat yang mengatasnamakan mereka sebagai (FPTU)? Bagaimana alternatif yang tepat dalam persoalan masalah tanah di kalangan masyarakat Tarok City? Bagaimana Status tanah di area Tarok City ? Pertanyaan di atas diharapkan dapat diketahui dalam kajian penulisan ini. Adapun pertanyaan penelitian adalah: Bagaimana kesiapan lembaga masyarakat di kawasan Tarok City terhadap pembangunan KPT tarok City? Penulisan ini bertujuan untuk: mendiskripsikan kesiapan lembaga masyarakat di kawasan City terhadap pembangunan.

\section{Tinjauan Pustaka}

Kajian ini bersifat terapan, maka beberapa kajian terkait dengan kajian Pembangunan Tarok City dapat diklasifikasikan sebagai berikut;

\section{Pembangunan Masyarakat}

Sekurang-kurangnya ada tiga komponen perencanaan dan pembinaan pedesaan (policy makers), agen dan masyarakat (adopters) (lihat Rogers 1983). Perencanaan adalah mereka yang secara teoritis mengembangkan konsep, strategi dan metodologi yang handal untuk pembinaan masyarakat. Mereka adalah kumpulan orang di belakang meja, berfikir, merumuskan dan melaksanakan fikiran dan gagasan melalui agent yang telah mereka siapkan. Agent umumnya adalah petugas yang berusaha menerjemahkan fikiran para perencana kepada masyarakat yang menjadi sasaran pembinaan. Para agen umumnya adalah kaki tangan perencana yang mungkin berasal dari luar maupun dari dalam masyarakat sasaran. Adapun masyarakat yang menjadi sasaran pembinaan adalah unsur penerima gagasan. Umumnya mereka menunggu dan seringkali bersifat pasif.

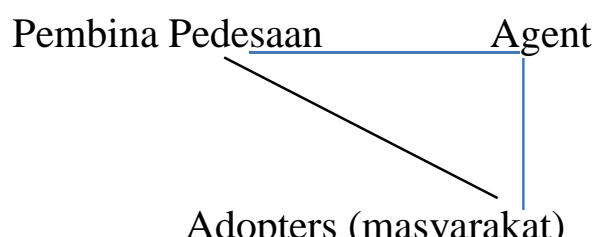

Ketiga unsur ini saling terkait dengan program yang dirancang. Secara teoritis perencanaan dan agen harus mengetahui dengan jelas hal-hal penting yang dilakukan dalam 
menjalankan program yang dirancang dan hal-hal yang patut dihindarkan. Para perencana dan agen harus sadar kedudukan mereka dari sudut pandang masyarakat yang menjadi sasaran adalah sebagai orang luar, orang asing yang mencoba memperkenalkan suatu ide kepada mereka. Walaupun sebagian dari agenadalah anggota masyarakat itu sendiri, tetapi dalam alam fikiran calon adapters, para agen sekarang sudah menjadi orang luar.

Sebagai orang luar para perencana dan agen sepatutnya menyadari status mereka sebagai orang asing itu. Tetapi dalam praktek pembangunan di berbagai pedesaan, hal ini kurang disadari. Perencanaan sering beranggapan bahwa mereka lebih tahu apa yang dibutuhkan masyatakat desa, dan bahkan dalam beberapa hal masyarakat desa sering dianggap tidak tahu apa-apa, sempit wawasan dan lainnya. Padahal dalam gambaran tertentu masyarakat desa tidaklah sama dengan gambaran itu. Mereka mengetahui apa yang dilakukan dan apa yang tidak dilakukan. Karena kekeliruan persepsi itu, banyak kasus masyarakat desa terkesan menolak rencana pembangunan yang ditawarkan.

Menurut perspektif perencana masyarakat desa seringkali dianggap tidak memahami tujuan pembangunan yang direncanakan, sehingga menolak untuk berpartisipasi. Namun berbagai studi menunjukkan bahwa gagasan menolak tersebut karena mereka memegang prinsip "safety first" (Scott, 1976). Dalam kasus introduksi teknologi pertanian misalnya, petani menolak untuk mengadopsi teknologi barukarena kuatir gagal panen. Lahan pertanian mereka yang terbatas merupakan satu-satunya sandaran penopang kehidupan keluarga mereka. Kalau saja terjadi gagal panen karena menggunakan teknologi baru, sudah dapat dibayangkan kesulitan hidup yang akan mereka hadapi.

\section{Kesiapan Masyarakat}

Kesiapan adalah keseluruhan kondisi seseorang atau individu ysng membuatnya siap untuk memberikan respon atau jawaban di dalam cara tertentu terhadap suatu situasi dan kondisi yang dihadapi (Eti Kurniati 2014). Kesiapan merupakan suatu pondasi dasar bagi suatu masyarakat atau pemerintah dalam menindaklanjuti terkait dengan kegiatan yang akan dilakukan kedepannya, tidak terkecuali untuk kegiatan pembangunan kawasan pendidikan terpadu Tarok City. Terdapat banyak hal yang mempengaruhi kesiapan masyarakat terutama terkait dengan keterampilan, pengetahuan dan kemampuan yang dimiliki masyarakat. berdasarkan pengertian di atas kesiapan masyarakat yang dimaksudkan yaitu kesiapan masyarakat terutama lembaga masyarakat dalam pembangunan Kawasan Pendidikan Terpadu (KPT) Tarok City.

\section{Partisipasi Lembaga Masyarakat (Adat)}

Partisipasi merupakan kata kunci dalam setiap program pemberdayaan masyarakat dan dijadikan acuan dalam setiap hasil kebijakan pemerintah. Pemberdayaan seringkali disebutkan dan dituliskan dalam setiap kegiatan tetapi tidak diaplikasikan dan tidak berarti sesuai maknanya.

Kata partisipasi sejajar maknanya dengan kata peran serta, ikut serta, keterlibatan atau proses belajar bersama saling mengerti, menganalisis, merencanakan dan melaksanakan tindakan oleh beberapa anggota masyarakat. Menurut Asngari (2011) partisipasi dilandasi pengertian yang sama yaitu saling berkomunikasi dan berinteraksi. Slamet (2003) menyatakan bahwa, partisipasi dalam masyarakat dalam pembangunan dibuktikan dari keikut-sertaan dalam kegiaatan pembangunan dan memanfaatkan serta menikmati hasil pembangunan.

Gavanta dan Valderma (Aristo, 2004) menyatakan bahwa partisipasi masyarakat memiliki tiga konsep yaitu 1) partisipasi politik yang berorientasi pada mempangaruhi dan mendudukan wakil-wakil rakyat secara aktif dalam proses kepemerintahan, 2) partisipasi 
sosial sebagai keikutsertaan masyarakat dalam pertimbangan penilaian, implementasi, peninjauan dan evaluasi berdasarkan aktivitas sosial dan 3) partisipasi warga berupa keikutsertaan warga dalam penetapan keputusan dewan dan proses kepemerintahan.

Partisipasi lembaga masyarakat dan agen menjadi sasaran pembangunan yang merancang dan memikirkan pembangunan pembangunan yang diperlukan oleh masyarakat. Dari semula para perencana mencoba mendalami segala kebutuhan masyarakat sebagai sasaran pembangunan, dan mencoba mengkalsifikasikan alternatif yang tepat untuk melaksanakan program pembangunan itu. karena perencanaan dimulai dari bawah, maka dalam sudut pandang model pembangunan, pendekatan ini disebut sebagai pendekatan dengan model bottom up development.

Pendekatan ini biasa digunakan oleh Lembaga Swadaya Masyarakat seperti Muhammadiyah, Nahdatul Ulama, LP3ES, Dian Desa dan lainnya. Lembaga seperti itu berusaha membina masyarakat desa dengan pemahaman kebutuhan hidup masyarakat yang dijadikan sasaran pembangunan. Sebagai contoh pengembangan gerabah Kasongan dalam membina potensi masyarakat desa melalui pendekatan partisipasif ini. Pada mulanya secara tradisonal hanya membuat gerabah untuk kebutuhan tradisional pedesaan, sekarang telah berkembang gerabah mereka menjadi konsumsi perkotaan. Seniman Sapto Hudoyo secara partisipatif mendidik masyarakat desa untuk menciptakan berbagai bentuk dan ornamen artistik pada gerabah yang mereka buat, sehingga kemudian dapat berwujud benda-benda souvenir buat orang-orang kota.

Pembangunan Tarok City justru berlawanan dari pembangunan bottom up developmentatau lebih bersifat Top Down Development, hal ini dapat dilihat dari sejumlah demonstrasi yang menentang pembangunan Tarok City selama setahun terhadap pemerintah daerah setempat. Artimya pembangunan yang direncanakan belumlah sesuai dengan kebutuhan dan kepentingan masyarakat sekitar.

Kelemahan utama dari pendekatan ini adalah pembinaan yang berjalan dalam waktu lama. Hal ini disebabkan karena keterbatasan modal kerja yang tersedia dan curahan perencana dan agen yang terbatas. Oleh sebab itu dalam banyak kasus, banyak proyek pembangunan yang dilakukan dengan pendekatan ini mengalami keberhasilan pada tahun permulaan namun menjadi menurun setelah ditinggalkan perencana.

\section{Partisipasi Masyarakat Suatu Tinjauan Sosiologis}

Kebudayaan diangap sebagai alat melayani proses pembangunan, sehingga kebudayaan harus disesuaikan dengan kepentingan-kepentingan pembangunan (Budiman, 2000). Dalam beberapa anggapan keseharian kebudayaan tradisional dan orang yang tradisional sering dianggap kendala pembangunan. Kebudayaan di sini merupakan modal yang dapat dimanfaatkan dalam pembangunan. Ide pembangunan kawasan pendidikan terpadu dapat dikembangkan untuk kepentingan masyarakat di sekitar kawasan untuk menggalang partisipasi masyarakat dalam pembangunan tersebut. Dalam hal ini kebudayaan betul-betul menjadi idiologi umum yang mensukseskan pembangunan.

Menurut Weber kebudayaan adalah kekuatan penting yang merubah tata ekonomi suatu masyarakat ke arah kemajuan, seperti terbukti dari peran kebudayaan di kalangan kaum Calvinis. Kepercayaan terhadap orang terpilih dalam kosmologi Calvinis membangkitkan semangat kerja yang memastikan seseorang terpilih atau tidak. Kepastian tersebut berkaitan dengan keselamatannya dalam keberhasilan di dunia (Weber, 1930). Keyakinan ini ditunjukkan Weber sebagai kekuatan yang besar dalam memunculkan organisasi kerja dalam mengatur perilaku ekonomi.

Lembaga masyarakat menjadi faktor penting dalam proses difusi inovasi pembangunan masyarakat karena institusi ini mengandung pengertian tentang akumulasi modal dan tenaga 
kerja yang menjadi kekuatan gabungan dalam perubahan yang dilakukan bersama. Lembaga masyarakat telah digunakan sebagai bagian institusi pemerintah semenjak zaman orde lama hingga sekarang. Hal ini dibuktikan oleh Sjafri Sairin (1991), dimana lembaga masyarakat menjadi dasar pembentukan nilai nepotisme dan melemahkan kendali tehadap sepak terjang aparat pemerintah.

Developmentalisme merupakan konsep pembangunan yang dipahami Dunia Ketiga sebagai alterernatif yang mau tak mau harus diselenggarakan. Dalam hal ini, realitas pembangunan berkait erat dengan peran penting pemerintah sebagai penyelenggara. Di hampir seluruh Dunia Ketiga, penafsiran konsep pembangunan dipahami sebagai perbaikan umum dalam standar hidup. Kehadiran pembangunan mesti dipahami sebagai sarana untuk memperkuat negara, terutama melalui proses industrialisasi yang mengikuti pola seragam dari negara satu ke negara lainnya. Pandangan seperti inilah yang kemudian memposisikan pemerintah sebagai subjek pembangunan dan memperlakukan rakyat sebagi objek, resipen, klien dan partisipan pembangunan.

Gavanta dan Valderma (Aristo, 2004) menyatakan bahwa partisipasi masyarakat memiliki tiga konsep yaitu 1) partisipasi politik yang berorientasi pada mempangaruhi dan mendudukan wakil-wakil rakyat secara aktif dalam proses kepemerintahan, 2) partisipasi sosial sebagai keikutsertaan masyarakat dalam pertimbangan penilaian, implementasi, peninjauan dan evaluasi berdasarkan aktivitas sosial dan 3) partisipasi warga berupa keikutsertaan warga dalam penetapan keputusan dewan dan proses kepemerintahan.

Partisipasidalam kamus Sosiologi Antropologi merupakan aktifitas atau keterlibatan terhadap suatu kondisi (situasi stimulus) dimana kondisi itu harus dihadapi (Al-Barry, 2001). Soerjono Soekanto (1993) berpandangan bahwa partisipasimerupakan proses mengidentifikasi atau menjadi peserta, artinya penerimaan atau penolakan, serta sikap acuh tak acuh terhadap apa yang disampaikan oleh aktivitasnya. Sedangkan Weber (Ritzer, 2003) mengatakan partisipasimerupakan keikut sertaan dalam proses sosial.

\section{Metode Penelitian}

Penelitian ini dilakukan dengan pendekatan kualitatif, hasil penelitian ini diharapkan dapat memberikan jawaban dan pemahaman terhadap partisipasi lembaga masyarakat dalam mengahadapi pembangunan Kawasan Pendidikan Terpadu. Penelitian ini dilakukan di Kawasan Pendidikan Terpadu di Jorong Tarok, Kanagarian Kapalo Ilalang Kecamatan Kayu Tanam Kabupaten Padang Pariaman Provinsi Sumatra Barat dengan alasan; 1) Merupakan Kawasan Pendidikan Terpadu berada, 2) Kawasan ini mengalami persoalan gugatan ke pengadilan oleh masyarakat atas dibangunnya Kawasan Pendidikan Terpadu berdasarkan data media lokal.

Sesuai dengan Tujuan Penelitian, telah dikumpulkan data sekunder dan data primer. Data Primer dikumpulkan melalui observasi, diskusi kelompok terfokus dan wawancara mendalam terhadap tokoh pimpinan adat, tokoh masyarakat, ninik mamak, cerdik pandai, pengusaha lokal, pemerintah dan anggota Dewan Perwakilan Daerah Pariaman. Dengan menggunakan beberapa teknik pengumpulan data tersebut, diperoleh secara komprehensif dan untuk validasi data digunakan teknik triangulation methode (Denzin, 1970, 1989 dan Olsen 2004). Analisa data dilakukan dengan menggunakan analisa data yang dikemukakan oleh Miles B. Mattew dan Michael Huberman.

\section{Hasil dan Pembahasan}

Berdasarkan hasil penelitian di lapangan diketahui bahwa partisipasimasyarakat terutama lembaga adat, menolak untuk mendukung secara positif pembangunan tersebut, 
karena dalam prosesnya dianggap tidak beretika terhadap lembaga masyarakat yang berwenang yaitu kelompok adat tanpa menggunakan pendekatan adat. Data ini diperoleh dari tiga orang pimpinan pada lembaga Adat di nagari koto Hilalang, pimpinan nagari, dan masyarakat biasa.

\section{Partisipasi Lembaga Adat}

Hasil temuan data di lapangan, berdasarkan wawancara dengan masyarakat 5 orang pimpinan adat masyarakat dapat diketahui bahwa secara positif masyarakat menolak pelaksanaan kegiatan, adapun masyarakat yang mendukung kegiatan ini dianggap bukan bagian dari kelompok masyarakat asli atau disebut juga dengan istilah pendatang. Masyarakat pendatang ini berkebun di sekitar wilayah pembangunan dan menjual tanah mereka ke pemerintah dengan imbalan ganti rugi tanah. Pimpinan adat menganggap sebagaian besar tanah tersebut merupakan hak wilayah adat atau disebut juga dengan tanah ulayat, karena wilayah tersebut berstatus tanah sewa Belanda dari kemilikan tanah ulayat.

Perselisihan ini ditengahi oleh Pemda Pariaman, namun mendapat penolakan dari pihak Ninik Mamak. Menurut niniak mamak menginginkan pihak Pemda yang menemui mereka untuk musyawarah dalam menyelesaikan persoalan tersebut. Sosialisasi selama ini tidak ada. Menurut mereka Pemda hanya bertanya bagaiman jika dibangun sekolah Perguruan Tinggi di Tarok City dan kemudian tidak ada kelanjutan atau pembahasan khusus mengenai itu. Pemda melayangkan undangan kepada niniak mamak sebanyak 3 sampai 4 kali undangan. Niniak mamak juga pernah mengundang Pemda untuk melakukan musyawarah, namun Pemda berpendirian berbeda dan juga tidak mau memenuhi undangan para niniak mamak Kenagarian Kapalo Hilalang. Terkait pihak kampus yang akan berdiri di Kenagarian Kapalo Hilalang ini sendiri, tidak ada yang melakukan pendekatan kepada masyarakat sekitar. Menurut Ninik Mamak mereka menganggap lahan tanah ulayat yang dibagikan Pemda kepada mereka sudah manjadi milik mereka, padahal tanah itu masih bersengketa atau berprakara.

Menurut Ninik Mamak untuk kampus yang akan berdiri di Tarok City tersebut, hendaknya melakukan pendekatan kepada warga atau masyarakat sekitar. Hal ini dikarenakan pihak Pemda tidak mengikut sertakan pihak adat dalam perencanaannya. Menurut Ninik Mamak sebagian dari tanah Tarok city merupakan tanah Ulayat milik nagari, bukan tanah milik negara seperti yang dijelaskan Pemda. Selain itu, Ninik mamak yang menyetujui pembangunan Tarok City dianggap orang asing atau pendatang yang menetap di sekitar wilayah tersebut dan diturunkan jabatannya sebagai Penghulu Ninik mamak saat ini di kalangan masyarakat Nagari Tarok.

Masyarakat yang menjual tanah untuk pembangunan Tarok City umumnya adalah masyarakat luar, bukan masyarakat asli dari Nagari Kampung Hilalang yang telah membeli tanah di sekitar area Tarok City. Bagi masyarakat kampung Hilalang merasa terhina jika Ninik mamak mereka tidak diajak berunding atau didatangi Pemda dalam rangka pembangunan Tarok City.

Munculnya aksi demo masyarakat terhadap Pemda dan DPRD adalah tidak tanggapnya mereka dalam pengganti rugian tanah dan Amdal yang berakibat buruk pada ekonomi pertanian dan peternakan mereka. Akibatnya adalah muncul demonstrasi masyarakat yang memperjuangkan hak mereka ke DPRD Kabupaten Padang Pariaman. Semenjak awal tahun 2017.

Selain itu sejarah tanah Tarok City dahulu adalah milik Nagari yang disewa Belanda. Belanda menyewa kepada Ninik mamak Nagari hingga masa Kemerdekaan Indonesia. Setelah merdeka tanah ini dipakai oleh TNI sebagai tanah militer. Setelah kami ajukan banding ke pengadilan pada masa presiden Susilo Bambang Yudoyono (SBY), tanah ini kami 
menangkan dan menjadi milik nagari kami. Namun setelah masa Presiden Jokowi, tanah ini diambil alih oleh pemerintah Daerah unruk melaksanakan pembangunan Tarok City.

\section{Partisipasi Warga Pembangunan Tarok City}

Difusi Inovasi pembangunan dalam masyarakat menyangkut penerimaan unsur-unsur baru dalam kehidupan mereka. Unsur-nsur baru tersebut tidak selamanya dapat diterima dengan mudah. Hal ini masyarakat mengalami dinamika dalam memahami secara internal dalam melakukan penyesuaian dalam interaksinya dengan praktek kehidupan baru. Hal ini difusi inovasi pembangunan Tarok City dapat dibedakan menjadi empat tahap:

1. Pengetahuan

Berdasarkan pembangunan yang dilaksnakan di area Tarok City, masyarakat mengetahui bahwa pembangunan tersebut berdampak baik bagi masyarakat, terutama bagi lembaga adat. Hanya saja persoalan tata krama dan sopan santun dalam pelaksanaan tersebut menjadikan lembaga adat merasa dihina dan dianggap remeh. Apalagi pelaksanaannya dilakukan di nagari mereka atau wilayah mereka serta mereka dianggap sebagai pemilik wilayah adat di sekitar itu. Selain itu masyarakat telah banyak mengetahui dampak pembangunan yang tidak menghitung kerugian terhadap masyarakat seperti kurangnya jumlah air untuk persediaan tanaman dan hewan ternak mereka. Akibatnya ratusan hektar pertanian mereka rugi dan ternak mereka sakit. Artinya mematikan perekonomian petani di kampung Hilalang. Selain itu ganti-rugi tanah tidak kunjung dilakukan pemerintah dan menyebabkan mereka rugi. Akhirnya mereka protes dan demonstrasi ke kantor DPRD Kabupaten Padang Pariaman. Bentuk dari demonstrasi ini adalah penolakan dari masyarakat dari rencana pembangunan di area Tarok City.

\section{Pengambilan Keputusan}

Berdasarkan uraian pertama, maka dapat diketahui bahwa Pengambilan keputusan yang dilakukan oleh pihak Pemda Padang Pariaman dalam rangka pembangunan Tarok City dianggap tidak berpihak kepada masyarakat. Selain itu dianggap memaksakan rencana pembangunan yang ingin dilaksanakan selama ini. Pengambilan keputusan ini tidak melibatkan lembaga resmi Adat kampung Hilalang. Akhirnya lembaga adat menolak secara resmi terhadap perencanaan itu, karena belum adanya kesepakatan resmi secara lembaga mengenai rencana pembangunan Tarok City.

Artinya pengambilan keputusan terhadap perencanaan tersebut masih bersifat sepihak sehingga mengakibatkanrendahnya partisipasi masyarakat dan belum menghasilkan kata setuju atau sepakat untuk melaksanakan pembangunan Tarok City. Kalaupun ada pengakuan Ninik mamak yang menyetujuinya dianggap persetujuan yang tidak resmi secara anggota Ninik Mamak kampung Hilalang dan dianggap sebagai Ninik mamak pendatang

\section{Konfirmasi}

Persetujuan atau konfirmasi menunjukkan kesepakatan bersama. Berdasarkan uraian di atas dapat diketahui bahwa belum ada kesepakatan antara pemerintah dengan lembaga adat kampung Hilalang. Artinya partisipasilembaga adat untuk saat ini menolak rencana pembangunan kawasan Tarok City. Hal ini didasarkan dari nilai dan etika adat Minangkabau yang kuat dianut oleh lembaga adat kampung Hilalang. Selain itu sejumlah demonstrasi merupakan bentuk penolakan masyarakat terhadap rencana pembangunan yang akan dilaksanakan. Maka idealnya Pemda haruslah menyelesaikan terlebih dahulu persoalanpersoalan yang terjadi antara masyarakat dengan Pemda terkait dengan pembangunan Tarok City.Penolakan dapat berubah menjadi penerimaan ketika ada solusi yang ditawarkan antara kedua belah pihak yang sedang mengalami sengketa. Konfirmasi merupakan bentuk 
partisipasimasyarakat secara langsung maupun tidak langsung yang diketahui dari bahasa dan perilaku masyarakat setempat.

Kalau dilaksanakannya pembangunannantinya, maka dapat diperkirakan tidak dapat berjalan dengan baik dan lancar. Terdapatnya persoalan antara lembaga masyarakat dengan pemerintah Daerah. Terutama masalah tanah, karena tanah adalah milik masyarakat secara lembaga dan kemungkinannya penuntutan tersebut adalah masyraakat terhadap tanah tersebut di tingkat Pengadilan Tinggi. Tanah yang dianggap milik komunal dan telah dimiliki mereka jauh sebelum negara ini ada.

\section{Penutup}

Sebagai kesimpulan dalam penelitian ini,masyarakat tidak memiliki kesiapan terhadap pembangunan Tarok City, dengan demikian masyarakat menunjukkan partisipasi yang rendah terutama dalam perencanaan pembangunan. Lembaga masyarakat tidak diikutsertakan atau belum adanya kesepakatan terhadap negosiasi yang dilakukan antara pihak lembaga masyarakat dan pihak Pemda Padang Pariaman. Saat penelitian ini berlangsung dapat dikatakan masyarakat masih menolak terhadap pembangunan karena adanya persoalan status tanah yang dianggap milik ulayat nagari bagi kalangan Adat. Lain halnya dengan pemerintah yang telah berhasil membuat surat tanah Tarok City pada Dinas Pertanahan yang merasa berkuasa atas seluruh tanah rakyat. Hal inilah yang menyebabkan ketidak setujuan dan penolakan masyarakat terhadap pembanguan Tarok City. Masyarakat terus berupaya mempertahankan tanahnya dan pemerintah berusaha melanjutkan pembangunannnya. Dengan demikian penelitian menunjukkan bahwa masyarakat tidak siap dengan akan dibangunnya Kawasan Pendidikan Terpadu (KPT) di Tarok City. Hal ini terlihat dari rendahnya antusiasme dan tingkat partisipasi lembaga masyarakat yang dibuktikan masih belum tuntasnya sengketa tanah ulayat dan kesepakatan ganti rugi yang tak kunjung ada penyelesaian.

\section{Daftar Pustaka}

Abdullah, Irwan. (1994). The Muslim Businessmen of Jatinom: Religious Reform and Economic Modernization in a javanese Town. Disertasi. University of Amsterdam

Afrizal. (2005). Pengantar Metode Penelitian Kualitatif dari Pengertian Sampai Penulisan Laporan. Padang: Labor Sosiologi FISIP UNAND.

Al Barry. (2001). Kamus Sosiologi Antropologi. Surabaya: Indah

Budiman, Arif. (2000). Pemberdayaan Pembangunan Dunia Ketiga. Jakarta: Pustaka Utama

Danim, Sadarwan. (1988). Menjadi Peneliti Kualitatif. Pustaka Setia: Bandung

Erman, Erwiza. (2005). Membaranya Batu Bara Konflik Kelas dan Etnik, Ombilin Sawahlunto 1892-1996. Jakarta: Penerbit Disentra

Huberman, Michael dan Miles B. Mattew. (1992). Analisis Data Kualitatif. Jakarta: Universitas Indonesia Press.

Iqbal, Hasan. (2002). Metodelogi Penelitian dan Aplikasi. Jakarta: Ghalia Indonesia. 
Koentjaraningrat. (1977). Metode-metode Penelitian Masyarakat. Jakarta: Gramedia Pustaka Utama

Terapan. Jakarta: LP3ES 1996. Pengantar Antropologi I. Jakarta: Pustaka Sinar Harapan

Ritzer, George. (2003). Sosiologi Ilmu Berprdigma Ganda. Jakarta: Prenedia Media

Roger. (1983). Division of Inovation. London: The Free Press

Scott, James. (1976). Moral Ekonomi Petani: Pergolakan dan Subsistensi di Asia Tenggara. Jakarta: LP3ES.

Sjafri Sairin. (1991). Dimensi Kebudayaan dalam Pembangunan Desa, makalah Seminar Nasional Optimalisasi Peran Desa sebagai Sumberdaya Potensial dalam Pembangunan Nasional, Universitas Merdeka Malang dan Depdagri, Malang, 6-7 Agustus.

Soekanto, Soerjono. (1990). Sosiologi. Jakarta: PT. Raja Grafindo . (1998). Pengantar Penelitian Hukum. Jakarta: UI Press

Sumner, W.G. (1940). Selected essays William Graham Sumner. New Haven, Yale University

Wirawan, Sarlito. (2002). Psikologi Sosial: Individu dan Teori Psikologi Sosial: Jakarta: Balai Pustaka. 